\title{
Multicultural Project Management Connectedness to National Culture: Case Study, the Nigerian System
}

\author{
Okpala Izunna Udebuana \\ Department of Communication and Translation Studies, National Institute for Nigerian Languages, Aba, Nigeria \\ Email address: \\ izunna.okpala@yahoo.com \\ To cite this article: \\ Okpala Izunna Udebuana. Multicultural Project Management Connectedness to National Culture: Case Study, the Nigerian System. \\ International Journal of Engineering Management. Vol. 3, No. 1, 2019, pp. 1-5. doi: 10.11648/j.ijem.20190301.11
}

Received: June 5, 2019; Accepted: July 3, 2019; Published: July 13, 2019

\begin{abstract}
Adapting to a formalized management style in this era of globalization represents an important managerial duty in various multicultural organizations of which project managers should be aware of. Inter-cultural competency such as understanding the major cultural differences between people from different locations and its integration to project management practices are critical to the success of modern project managers. National culture plays significant role in the growth of an organization and it is very relevant in choosing specific management style in an organization that is culturally diverse in terms of employability. This study investigates the impacts and the relationship between national culture and different management styles of a multicultural project manager. The benefits of culturally diverse teams and project management processes are inherent in vast mixture of different points of view, values, skills and talents. The study makes use of qualitative methodology to investigate non-numeric facts and also the quantitative approach to quantify data using feedbacks from various respondents to choose a hypothesis. A questionnaire was developed to capture various views from industry professionals. In summary, National culture has a direct relationship with multicultural project manager in Nigeria and the most practiced and viable management style in Nigeria is the administrative management style.
\end{abstract}

Keywords: Culture, National Culture, Management Styles, Project Management, Multicultural Organization

\section{Introduction}

Workforce diversity affects globalisation; there is need for greater understanding of leadership among the project teams with multicultural people [1]. Few researchers have argued that cultural diversity in the workplace results to a decrease in the performance of the workers [2]." They argued that individuals and organizations in the project network will have different values, beliefs, and norms". This study is informed by the need to ascertain the management styles that thrives in the Nigerian system with regards to National culture. Multicultural project managers cannot effectively accomplish projects without giving considerations to their management styles and national culture [3]. Just like in countries such as Saudi Arabia, at least 30 percent of project managers are forced to try different management styles to fit specific demands of multicultural organizations under their watch [4].

The principal focus of this study is to analyse the impacts of National culture and its perceived relationship with management styles in the context of multicultural organization on theoretical and empirical level. This research has distinct tasks that converges to form a whole.

Research Objectives:

1. Formulating research questions and hypothesis

2. Carrying out theoretical and literature overview

3. Developing the questionnaire

4. Creating email template of respondents

5. Analysing Google infographics from respondents

6. Analysing data with PSPP Software

7. Choosing a hypothesis

\section{Literature Review}

One factor that has challenged the application of a given management style in an organization is their national culture. Studies such as Frantz and Jain [5] recognise that there are still conflicting ideologies on the extent to which national culture is considered a management style and would suit a project manager of a multicultural organization [6]. Due to 
the different research findings, theoretical frameworks and dynamism in contemporary organizations, this chapter provides a systematic review of current knowledge on the research topic, substantive findings from different scholars, and conceptual models as well as methodological contributions to the connectedness between national culture and different management style of a multicultural project manager. Culture refers to the pattern of traits, and products considered being the expression of particular population, or community [7]. In most cases, the most predominating attitudes and behaviours, which seem to characterize the functioning of the group and organization, are considered culture. Since 1980s, culture has been used in the business jargon while referring to the attitudes and behaviours of organizational members [8-9]. Furthermore, culture has been able to acquire greater awareness over the decades as businesses seem to continue interacting at the global level and the needs of understanding different cultures which is becoming a business necessity [10]. Eriksson et al. viewed culture as a collective programming of the mind distinguishing the members of one group from another [11]. Hofstede's relied on the three layers of mental programming to construct the culture triangle. First is the individual mental programming which refers to one's personality that is unique to a specific person partially transmitted through inheritance. The second layer is the collective mental programming. This encompasses what individuals learn from one another based on its specificity to that group of persons. The collective mental programming can also be said to be the culture of the people. The last is the universal mental programming which constitutes human nature and focuses on every human being. It includes survival instincts and is also significantly transmitted through inheritance. Trivellas and Drimoussis attempted to interpret the connection between styles of management and national culture by noting that when project managers apply a given style that suit the culture then the organization is likely to realize profitability [12]. Though National culture is the most import factor to consider, they failed to note that performance is not only reflected through the national culture but also through the project managers experience, which gives an organization implicit balance for strategic management. In support of this position, Venables Tan and Miliszewska reviewed different project management practices in different national cultures concluding that simple relationship such as 'understanding national culture' lead to good approach in project planning and execution in a culturally diverse organization [13]. Takahashi, Ishikawa and Kanai also noted that differences in national culture and values were the reason for different management approaches adopted in the start and implementation of projects while researching on 'qualitative and quantitative studies of leadership in multinational settings,' [14]. Management styles that can be adopted by a multicultural organization are;

a. Authoritarian style: Managers who are high in conscientiousness and possibly low in agreeableness tend to prefer authoritarian management style [15]. These managers tend to command and control their subordinates with fear and uncertainty.

b. Consultative style: This management style is where managers consult other team members before arriving at a decision [16]. This is in contrast to the autocratic management style.

c. Extroverted Style: These managers are typically softhearted, understanding, compassionate, charismatic and considerate [15]. They are high in agreeableness.

d. Introverted style: This is the opposite of the extroverted management style.

e. Political style: This is found in managers who are outspoken, competitive, headstrong and manipulative. It's all about politics and not the ethics of the organization.

f. Administrative style: This style finds a rational way to design an organization as a whole. The theory generally calls for a formalized administrative structure, a clear division of labour, and delegation of power and authority to administrators relevant to their areas of responsibilities [17].

g. Democratic style: The managers that fall under this category are open minded; they have a great degree of intellectual curiosity, preferring a diversity of ideas. They are imaginative and are more willing to experiment in a democratic setting [15].

h. Laissez-faire style: This is also known as delegative management style [18]. Management in these category carters for managers who are high in agreeableness, with high degree of trust in others. It is easy for them to trust their team and their subordinates. It's a type of management style that the leaders hands-off and allow group members to make decision. They often adopt the strategy of "Trust and verify".

i. Collaborative style: This is a collection of various management techniques that enlighten a sense of unity and teamwork among managers, supervisors and employees within a business organization [19].

\section{Methodology}

The research takes a qualitative and quantitative approach in order to investigate non-numeric and numeric data concerning phenomenological points of national culture, different management skills and project management in multicultural organizations. Furthermore, issues such as perception of managers on different management styles were deciphered qualitatively as seen in the literature review.

This research aims to transform "arguments believed" into "arguments known" and as such, while there are two major research philosophies identified in the topic (positivist and interpretivist), our scope stretches beyond them.

Hypotheses 1: Multicultural Project management has a direct relationship with National culture in Nigeria and thus impacts the organizational management style.

Hypotheses 2: Multicultural Project management does not have direct relationship with National culture in Nigeria and thus does not impact the organizational management style. 


\section{Data Analysis}

Data analysis was introduced as an approach to get results from questionnaire. Quantitative analysis was performed on the data with the use of google docs infographics, and PSPP software for descriptive frequency analysis. In addition, we used research papers from reputable journals to support the solution.

\subsection{Method of Data Collection}

Data was collected via questionnaire and each answer was quantified in order to be chosen as a viable hypothesis. Analysis was done based on information supplied by people;

(1) working in a multicultural organization resident in Nigeria

(2) who has at least between 1-3 years of experience on the job

(3) who can speak and write English

(4) Who understands the topic.

\subsection{Questionnaire Format}

The questionnaire for this research is open ended with the inclusion of additional columns for further explanation in order to understand the reason behind each answers. It was constructed in a manner to reflect the hypothesis and other factors that is needed to dig deep into multicultural project management in Nigeria. The questions are linked together in such a way that question one relates to question two then other questions in that succession. On possible outcomes and evaluation. The rationale for this design is to enable the study to obtain and put into context research questions and hypotheses.

\subsection{Response Rate}

The sample size for this research consisted of 220 requests to the major employees at the telecommunication and oil companies in Nigeria.

Table 1. Response rate from questionnaire.

\begin{tabular}{lll}
\hline Response & Frequency & Percentage \\
\hline Responded & 146 & $66 \%$ \\
Not responded & 74 & $34 \%$ \\
Total & 220 & $100 \%$ \\
\hline
\end{tabular}

The Demography for this research is the Nigerian population and the main cities that provided information with regards to the questionnaire are Abuja (capital), Lagos, Port Harcourt, Enugu, Owerri, Kaduna, Uyo, and Benin. Companies where the respondents work in are MTN, Airtel, 9 Mobile, Glo Mobile, NNPC and Shell.

\subsection{Analysis with Google Infographics}

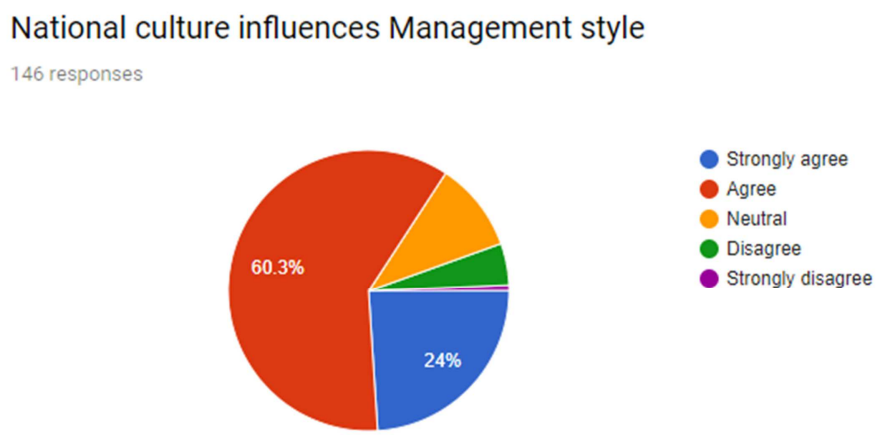

Figure 1. Infographics National culture influences management style.

It can be deduced from the result that $61.2 \%$ of the people agrees that National culture influences management style. While $24.8 \%$ strongly agrees with the notion. With this, I pick Hypotheses 1 as the most viable option in this research.

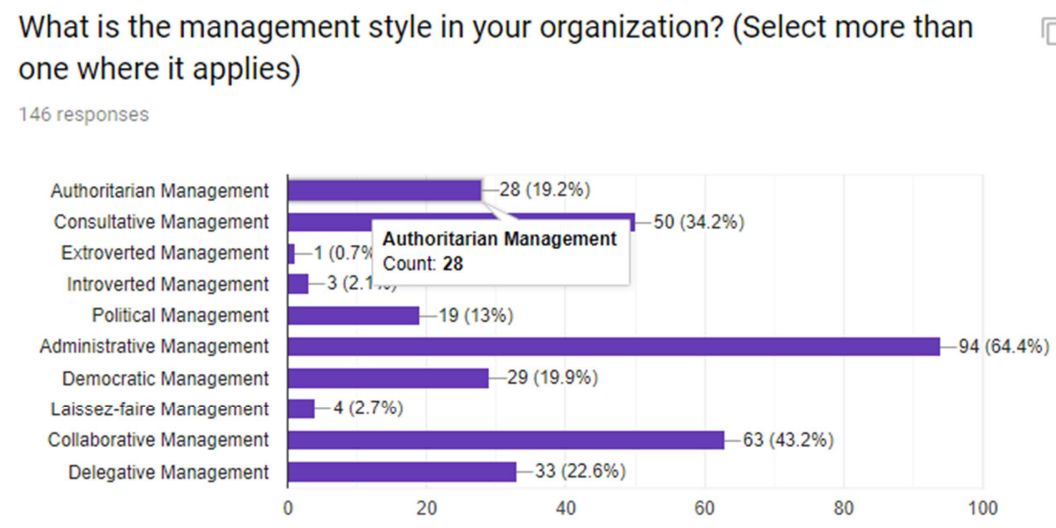

Figure 2. Management styles. 
From the chart, the most popular management style that correlates more with multicultural organization in Nigeria is Administrative management.

\section{Which of these success factors is more important in a multicultural organization?

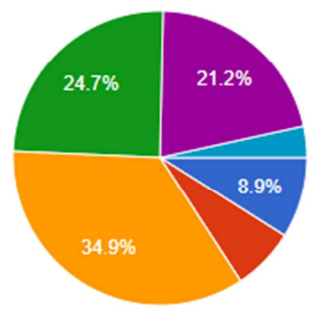

More organized business flow

Easy flow of business ideas

The Acceptability factor that gives everyone a sense of belonging

- Equality without segregation within the work environment

- Ability to deal with customers from diverse background

Easy penetration in another location in terms of expansion

Figure 3. Success factors in a multicultural organization.

The success factor that is more important in multicultural organization is the acceptability factor that gives everyone a sense of belonging.

\subsection{Analysis with PSPP Software}

Quantifying the values for Likert scale and recoding the sample data.

Table 2. Data Recode having values 1 and 2 only.

\begin{tabular}{ll}
\hline ANSWERS & QUANTIFIED VALUE \\
\hline Strongly Agree & 1(Agree) \\
Agree & 1(Agree) \\
Neutral & - \\
Disagree & 2(Disagree) \\
Strongly Disagree & 2(Disagree) \\
\hline
\end{tabular}

Running the Descriptive frequency code after recode for the question: National culture influences management style.

Table 3. Descriptive frequency analysis 1.

\begin{tabular}{llllll}
\hline \multicolumn{6}{l}{ Table: RECODE - National culture influences Management style } \\
\hline $\begin{array}{l}\text { Value } \\
\text { Label }\end{array}$ & Value & Frequency & Percent & Valid Percent & Cum Percent \\
\hline Agree & 1 & 125 & 87.41 & 94.69 & 94.69 \\
Disagree & 2 & 7 & 4.89 & 5.30 & 100 \\
& $\cdot$ & 11 & 7.69 & Missing & \\
Total & & 143 & 100 & 100 & \\
\hline
\end{tabular}

For the Question: If national culture dictates management style, project management processes becomes stronger.

Table 4. Descriptive frequency analysis 2.

\begin{tabular}{llllll}
\hline \multicolumn{6}{l}{ RECODE: National culture makes management processes stronger } \\
\hline $\begin{array}{l}\text { Value } \\
\text { Label }\end{array}$ & Value & Frequency & Percent & $\begin{array}{l}\text { Valid } \\
\text { Percent }\end{array}$ & $\begin{array}{l}\text { Cum } \\
\text { Percent }\end{array}$ \\
\hline Agree & 1 & 80 & 55.94 & 67.22 & 67.22 \\
Disagree & 2 & 39 & 27.35 & 32.77 & 100 \\
& $\cdot$ & 24 & 17.09 & Missing & \\
Total & & 143 & 100 & 100 & \\
\hline
\end{tabular}

The affirmative frequency is greater than $50 \%$ with valid data, this means the calculation affirms hypothesis 1 . We therefore accept hypotheses 1 .

\section{Conclusion}

It can be summarized that National culture in Nigeria influences management style and the most practiced management style for multicultural organizations in Nigeria is the Administrative management style. It is important to clarify that national culture is geographically related, whilst management style is an international adopted style which sometimes overrides national culture where there is a conflict, but to adopt and grow in a geographical location requires a special skill to mitigate the effect of culture bias. The most acceptable management style in Nigeria which relates to how project managers handles projects in Nigeria is the administrative project management style. This style finds a rational way to design an organization as a whole. It calls for a formalized administrative structure, a clear division of labour, and delegation of power and authority to administrators relevant to their areas of responsibilities. Conceptual and literal basis was used to support the connectedness between national culture and different management style of a multicultural project manager from reviewed respondents.

\section{References}

[1] Savelsbergh, C. M., Havermans, L. A., \& Storm, P. (2016). 'Development paths of Project Managers: What and how do Project Managers learn from their Experiences'. International Journal of Project Management, 34(4), 559-569.

[2] Comu, Semra, Hakan I. U., and John E. T. (2010) "Dual impact of cultural and linguistic diversity on project network performance." Journal of management in engineering 27(3), 179-187.

[3] MacNab, B. R. and Worthley, R., (2012) 'Individual characteristics as predictors of cultural intelligence development: The relevance of self-efficacy'. International Journal of Intercultural Relations, 36(1), 62-71.

[4] Stevens, R. H. and Ogunji, E., (2011) 'Preparing business students for the multi-cultural work environment of the future: A teaching agenda'. International Journal of Management, 28(2), 528. 
[5] Frantz, T. and Jain, A. K., (2017) 'Relating CEO leadership behavior and organisation culture in the India context'. Leadership and Organisation Development Journal, 45-78.

[6] Mittal, R. and Elias, S. M., (2016) Social power and leadership in cross-cultural context'. Journal of Management Development, 35 (1), 58-74.

[7] Hofstede, G., (2003) 'What is culture? A reply to Baskerville'. Accounting, Organisations and Society, 28 (7), 811-813.

[8] Daft, R. L., \& Marcic, D. (2014). Building management skills: An action-first approach. Mason, OH: South-Western Cengage Learning.

[9] House, R. J., Hanges, P. J., Javidan, M., Dorfman, P. W. \& Gupta, V. (2004) Culture, Leadership, and Organizations: The GLOBE Study of 62 Societies. Thousand Oaks, CA: Sage.

[10] Mohammed, U. K., White, G. R., \& Prabhakar, G. P. (2009). 'Culture and Conflict Management Style of International Project Managers'. International Journal of Business and Management, 3(5), 107-122.

[11] Eriksson, M., Lillieskold J., Jonsson, N., and Novosel, D. (2002) 'How to Manage Complex, Multinational R\&D Projects Successfully'. Engineering Management Journal, 14, 53-61.

[12] Trivellas, P. and Drimoussis, C. (2013) 'Investigating leadership styles, behavioural and managerial competency profiles of successful project managers in Greece'. ProcediaSocial and Behavioural Sciences, 73, 692-700.

[13] Venables, A., Tan, G. and Miliszewska, I. (2013) 'Developing Cross-Cultural Awareness in IT: Reflections of Australian and Chinese Students'. Journal of Information Technology Education: Innovations in Practice, 12(91-99).

[14] Takahashi, K., Ishikawa, J. and Kanai, T. (2012) 'Qualitative and quantitative studies of leadership in multinational settings: Meta-analytic and cross-cultural reviews'. Journal of World Business, 47 (4), 530-538.

[15] McDermott, A. (2019). The Top 7 Management Styles: Which Ones Are Most Effective? Retrieved April 2019 from https://www.workzone.com/blog/management-styles/

[16] Casestudyinc (2011) Consultative Management. Retrieved April 2019

http://www.casestudyinc.com/glossary/consultativemanagement

[17] Thwala, S. (2015). The comprehensively explanation on the origin of administrative theory by means of an exposition of the respective contributions of its main theorists namely fayol, weber and barnard.

[18] Cherry, K. (2019). What Is Laissez-Faire Leadership? (The Pros and Cons of the Delegative Leadership Style). Retrieved April 2019 https://www.verywellmind.com/what-is-laissezfaire-leadership-2795316

[19] Tutorialspoint.com (2019). Collaborative Management Introduction. Retrieved April 2019 https://www.tutorialspoint.com/collaborative_management/col laborative_management_introduction.htm

[20] Hofstede, G. and Usunier, J.C., (2003) 'Hofstede's dimensions of culture and their influence on international business negotiations'. International business negotiation, 137-153.

[21] Korzilius, H., Bücker, J.J. and Beerlage, S., (2017) 'Multiculturalism and innovative work behavior: The mediating role of cultural intelligence'. International Journal of Intercultural Relations, 56, 13-24.

[22] Lauring, J. and Selmer, J., (2010) 'Multicultural organizations: Common language and group cohesiveness'. International journal of cross cultural management, 10(3), 267-284.

[23] Lester, G. V., Virick, M. and Clapp-Smith, R. (2016) 'Harnessing Global Mindset to Positively Impact Advances in Global Leadership through International Human Resource Management Practice's. In Advances in Global Leadership (325-349).

[24] Leung, A. and Chiu, C. (2010) 'Multicultural Experience, Idea Receptiveness, and Creativity'. Journal of Cross-Cultural Psychology, 41(5-6), 723-741.

[25] Lok, P. and Crawford, J. (2004) 'The Effect of Organisational Culture and Leadership Style on Job Satisfaction and Organisational Commitment: A cross-national comparison'. Journal of management development, 23 (4), 321-338.

[26] Martens, M. L. and Carvalho, M. M., (2016) 'Key factors of sustainability in project management context: a survey exploring the project managers' perspective'. International Journal of Project Management.

[27] Mittal, R., (2015) 'Charismatic and transformational leadership styles: A cross-cultural perspective'. International Journal of Business and Management, 10 (3), 26.

[28] Verma, N., Bhat, A. B., Rangnekar, S. and Barua, M. K. (2015) 'Association between leadership style and decision making style in Indian organisations'. Journal of Management Development, 34 (3), 246-269. 